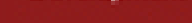

\section{Contesting the neoliberalisation of higher education through student-faculty partnership}

\section{Teguh Wijaya Mulya}

To cite this article: Teguh Wijaya Mulya (2018): Contesting the neoliberalisation of higher education through student-faculty partnership, International Journal for Academic Development, DOI: $10.1080 / 1360144 X .2018 .1520110$

To link to this article: https://doi.org/10.1080/1360144X.2018.1520110

曲 Published online: 17 Sep 2018.

Submit your article to this journal 준

View Crossmark data $₫$ 


\title{
Contesting the neoliberalisation of higher education through student-faculty partnership
}

\author{
Teguh Wijaya Mulya (iD) \\ Faculty of Psychology, University of Surabaya, Surabaya, Indonesia
}

\begin{abstract}
Student-faculty partnership has been researched by contemporary academic developers, particularly its outcomes and challenges. However, theoretical discussions linking it with larger social-educational-political discourses are still lacking. This reflection aims to help fill the gap by analysing how student-faculty partnership might contest the neoliberalisation of higher education. It argues that, by positioning partnership as the basis for learning, student-faculty partnership provides an alternative discourse to contest the marketisation and corporatisation of higher education, the (re)production of learners as competitive and self-interested, and the standardisation and mechanisation of learning.
\end{abstract}

\section{ARTICLE HISTORY}

Received 22 August 2017

Accepted 12 July 2018

\section{KEYWORDS}

Neoliberalism;

student-faculty partnership; students as partners

\section{Introduction}

The practice of student-faculty partnership has recently drawn the attention of academic developers, because it offers possibilities to create more democratic, engaging, inclusive, and (co-)creative learning conditions (Healey, Flint, \& Harrington, 2014; Matthews, 2016). A common approach taken in these studies is to report the outcomes, challenges, and opportunities of a specific partnership programme (Mercer-Mapstone et al., 2017), while a smaller number have discussed student-faculty partnership more theoretically. These include, for example, Cook-Sather's (2014) reading of studentfaculty partnership as a threshold concept, or Cook-Sather and Felten's (2017) work on partnership and cosmopolitanism. The current reflection seeks to advance such theoretical engagement by examining student-faculty partnership in relation to the neoliberalisation of higher education. Specifically, it explores the ways student-faculty partnership might contest some of the neoliberal discourses that increasingly underpin teaching and learning practices today.

Neoliberalism is 'the agenda of economic and social transformation under the sign of the free market' (Connell, 2013, p. 100). It not only promotes free trade, privatisation, and tax reduction (Harvey, 2005), but also encourages the encroachment of economic rationalities into various spheres of life (Connell, 2013). In higher education contexts, I have argued elsewhere (Wijaya Mulya, 2016) that neoliberalism operates through discourses of competitiveness, marketisation, and standardisation. 
A number of studies on academic development have discussed neoliberalism; however, none has explicitly linked it with student-faculty partnership. Barnes and Jenkins (2014), for example, critiqued the positioning of students/lecturers as consumers/service providers by arguing that it denies both sides' pedagogic rights to personal enhancement, social inclusion, and civic participation. Edmond and Berry (2014) investigated the impact of the neoliberal discourse of employability on student engagement, in which engagement is being (re)defined as a CV building process instead of reciprocal learning. While Barnes and Jenkins (2014) did not discuss possibilities of resistance, Edmond and Berry (2014) presented examples of resistance only in the form of student union protests against neoliberal policies. They suggested future research to explore the ways alternative discourses 'can be harnessed in a joint effort to challenge the neoliberal university' (p. 14), which is what this reflection is aiming for in examining the discursive potential of student-faculty partnership.

\section{Ways in which student-faculty partnership may contest neoliberal discourses in higher education}

Student-faculty partnership provides an alternative means for understanding teaching and learning beyond the discourses offered by neoliberalism. This section demonstrates how three neoliberal discourses - marketisation, competitiveness, and standardisation - have given shape to contemporary higher education, and how student-faculty partnership may contest these discourses.

\section{Contesting the marketisation and corporatisation of higher education}

Neoliberalism (re)positions higher education as a commodity: it is sold in the market, managed like a company, and delivers benefits for stakeholders (Edmond \& Berry, 2014). The purpose of higher education is often narrowed down to producing skilled labour for businesses and industries. Curricula are continuously re-oriented to the demands of the labour market. Work-related competencies become both the starting point and end goal of learning. Lecturers are service providers; students and funders are consumers or investors whose satisfaction must be attended to (Barnes \& Jenkins, 2014). A university leader must be a market-oriented CEO who is skilful in management, budgeting, and advertising (Connell, 2013).

While corporatisation and marketisation of contemporary higher education might be inevitable, student-faculty partnership at least offers an alternative way of seeing it. Staff and students are not necessarily framed in a consumer-provider relationship, but as partners who work together around shared values such as collegiality, mutuality, and equality (Matthews, 2016). Research, learning, and curricula are not always based on market demands or work-related competencies, but may also focus on knowledge and skills needed for personal growth, community development, or social transformation. University leaders are no longer only CEOs focused on profit and managing resources, but democratic leaders who listen, accommodate, and make decisions for the common good. Student-faculty partnership, particularly at the institutional level, may open up the possibility for universities to become more like communities, rather than companies or commodities. 


\section{Contesting the (re)production of learners as competitive and self-interested}

Competitive individuals/institutions are vital for a neoliberal economy in which everyone must strive to survive, accumulate wealth, and achieve status. In higher education contexts, to be competitive is seen as crucial for students' future survival in the labour market (Edmond \& Berry, 2014); therefore, competition becomes increasingly acceptable as the main way to view learning and learners. Students' learning is evaluated as individual performance and quantified into grades. Grades compare, sort, and position students in hierarchies, through which they come to perceive themselves as standing in (competitive) relation to others. Joining competitions is then encouraged by universities, as they may bring in trophies and impress the market. Consequently, learning becomes self-interested, fixated on individuals' grades, and a competition for highpaying jobs.

Student-faculty partnership provides a set of ideas to give meaning differently to learning, for moving beyond competition and self-interest. Instead of individualism, student-faculty partnership promotes a sense of community and belonging among students and staff (Healey et al., 2014). In a situation where decisions are made together, competition may not be as important as the value of caring-and-sharing. Opportunities for students to design their learning - including learning assessment may open up spaces for them to think about the common good, rather than individuals' success. Grades or trophies may not be as highly valued when learning is mutual rather than competitive. In this way, student-faculty partnership reignites the social purposes of the university, such as enactment of democratic values, social justice, or inclusiveness (Apple, 2005), which have increasingly been superseded by market-driven priorities.

\section{Contesting the standardisation and mechanisation of learning}

Within the neoliberal logic, the university needs to demonstrate accountability to stakeholders using a set of performance standards that can be measured, quantified, and compared - including in the case of learning. Syllabi, lesson plans, and learning assessments are standardised to ensure that all students in all classes accomplish the pre-determined, externally imposed learning objectives regardless of who the lecturers are (Apple, 2005). Teaching becomes a mechanistic transfer of knowledge, and assessment becomes rubric-based scoring. Learning becomes the drilling of specific competencies useful for future work (Connell, 2013).

The discourse of student-faculty partnership poses a significant challenge to this neoliberal way of constituting learning. Learning is neither pre-determined nor externally imposed, but instead creative, reflective, and reciprocal (Healey et al., 2014). Learning objectives are not always or only market-driven or work-oriented, but generated in bottom-up ways and rooted in staff and students' social and cultural contexts. Teaching becomes less mechanistic and more democratic. Learning processes cannot be standardised because they are continuously negotiated, and learning outcomes could be unexpected. The quality of learning cannot be assessed, quantified, and compared against one-size-fits-all standards, because assessment criteria could be different for each class or individual. 


\section{Conclusion and implications for academic developers}

The hegemonic waves of neoliberalism in higher education have left many academic developers feeling helpless or crippled, particularly when asked: 'What is the alternative?' While there is no simple answer to such a complex situation, Roxå and Mårtensson (2017) suggested that paying attention to our everyday experiences, engaging in continuous problematisations, and sharing with others might be beneficial in order to find, circulate, and strengthen alternative discourses. In this reflection, I have argued that student-faculty partnership might at least provide such an alternative discourse to contest the marketisation of higher education, standardisation of learning, and competitive or self-interested ways of being a learner.

This reflection invites academic developers to be reflexive in relation to the ideological complexities of implementing student-faculty partnership, and what the ramifications might be. Academic developers may advocate student-faculty partnership if they aspire to disrupt some of the neoliberal logics and practices in contemporary higher education, while being aware that it can still be re-appropriated by neoliberalism.

\section{Acknowledgments}

Thanks to the Centre for Teaching, Learning, and Curriculum Development, University of Surabaya, for funding this project.

\section{Disclosure statement}

No potential conflict of interest was reported by the author.

\section{Funding}

This work was supported by the Centre for Teaching, Learning, and Curriculum Development at the University of Surabaya.

\section{Notes on contributor}

Teguh Wijaya Mulya is a lecturer in the Faculty of Psychology, University of Surabaya, Indonesia.

\section{ORCID}

Teguh Wijaya Mulya (D) http://orcid.org/0000-0002-8899-1157

\section{References}

Apple, M. W. (2005). Education, markets, and an audit culture. Critical Quarterly, 47(1-2), $11-29$.

Barnes, C., \& Jenkins, C. (2014). Student satisfaction negates pedagogic rights, theirs and ours! Student Engagement and Experience Journal, 3(2). doi:10.7190/seej.v3i2.97 
Connell, R. (2013). The neoliberal cascade and education: An essay on the market agenda and its consequences. Critical Studies in Education, 54(2), 99-112.

Cook-Sather, A. (2014). Student-faculty partnership in explorations of pedagogical practice: A threshold concept in academic development. International Journal for Academic Development, 19(3), 186-198.

Cook-Sather, A., \& Felten, P. (2017). Ethics of academic leadership: Guiding learning and teaching. In F. Su \& M. Wood (Eds.), Cosmopolitan perspectives on academic leadership in higher education (pp. 175-192). London: Bloomsbury.

Edmond, N., \& Berry, J. (2014). Discourses of 'equivalence' in HE and notions of student engagement: Resisting the neoliberal university. Student Engagement and Experience Journal, 3(2). doi:10.7190/seejv3i2.90

Harvey, D. C. (2005). A brief history of neoliberalism. Oxford: Oxford University Press.

Healey, M., Flint, A., \& Harrington, K. (2014). Engagement through partnership: Students as partners in learning and teaching in higher education. Heslington, York: The Higher Education Academy.

Matthews, K. E. (2016). Students as partners as the future of student engagement. Student Engagement in Higher Education Journal, 1(1).

Mercer-Mapstone, L., Dvorakova, S. L., Matthews, K. E., Abbot, S., Cheng, B., Felten, P., ... Swaim, K. (2017). A systematic literature review of students as partners in higher education. International Journal for Students as Partners, 1(1).

Roxå, T., \& Mårtensson, K. (2017). Agency and structure in academic development practices: Are we liberating academic teachers or are we part of a machinery suppressing them? International Journal for Academic Development, 22(2), 95-105.

Wijaya Mulya, T. (2016). Neoliberalism within psychology higher education in Indonesia: A critical analysis. Anima Indonesian Psychological Journal, 32(1), 1-11. 